\title{
Komunistyczna Partia Zachodniej Ukrainy i tzw. proces łucki
}

Komunistyczna Partia Polski (a także działające w jej strukturach Komunistyczna Partia Zachodniej Białorusi i Komunistyczna Partia Zachodniej Ukrainy ${ }^{1}$ ) zajmuje szczególne miejsce w historii polskiego ruchu robotniczego oraz na arenie politycznej II RP. Była to partia konsekwentnie rewolucyjna, przejawiająca nieraz większą niż rosyjscy bolszewicy ortodoksję ideologiczną. Ugrupowanie to od samego początku swej działalności dążyło do przeniesienia leninowsko-marksistowskich koncepcji i rozwiązań na grunt polski, zamierzając ustanowić w Polsce system komunistycznej dyktatury całkowicie podporządkowanej Sowietom. Jednocześnie był to ruch marginalny, wyróżniający się ideologicznym dogmatyzmem i radykalizmem w działaniu, nierzadko dalej idącymi niż rosyjscy bolszewicy. Komuniści polscy przewidywali bowiem, że rewolucja komunistyczna w bardziej uprzemysłowionej Polsce może okazać się bardziej zaawansowana niż w chłopskiej Rosji ${ }^{2}$. W ogóle w początkowym okresie istnienia partii komunistycznej w przedwojennej Polsce rosyjscy komuniści postrzegani byli przez polskich rewolucjonistów jako niezbyt proletariaccy — bardziej o charakterze chłopskim niż robotniczym. Działacze KPP byli także przekonani o swej kulturowej wyższości nad swymi rosyjskimi odpowiednikami ${ }^{3}$. Aktywiści KPP byli też ludźmi prawdziwie ideowymi i posłusznymi, o głębokiej wierze w sprawę, o którą walczyli. Związanie się z komunizmem w okresie przedwojennym z pewnością nie może więc zostać uznane za wybór koniunkturalny. Zdecydowanie się właśnie na taką,

${ }^{1}$ Por. S. Iwaniuk, Prawdy i mity o KPZB, „Czasopis” 2008, nr 12 (215), s. 37; S. Łukasiewicz, Zdrada stanu. Działalność Komunistycznej Partii Zachodniej Białorusi w Wilnie w latach 1930-1935, „Ogrody Nauk i Sztuk” 2012, nr 2, s. 77.

2 M. Korkuć, W II Rzeczypospolitej, [w:] Komunizm w Polsce. Zdrada, zbrodnia, zakłamanie, zniewolenie, red. M. Kuś, Kraków 2012, s. 46-47.

3 J.A. Reguła, Historia Komunistycznej Partii Polski w świetle faktów i dokumentów, Toruń 1994, s. 25. 
a nie inną drogę polityczną — czy szerzej, życiową — oznaczało radykalny sprzeciw wobec otaczającej rzeczywistości i funkcjonowanie w warunkach stałego niebezpieczeństwa, a także poświęcenie własnego szczęścia i osobistych interesów w imię ideologii, która miała zaprowadzić nowy, sprawiedliwy świat. Trudno bowiem przypuszczać, że któryś z przedwojennych polskich komunistów fantazjował wówczas o stanowiskach i apanażach, za to z całą pewnością godził się na życie w nieustanym zagrożeniu oraz strachu przed aresztowaniem i więzieniem ${ }^{4}$.

Komuniści polscy, od samego początku organizacyjnie uzależnieni od radzieckich ośrodków decyzyjnych ${ }^{5}$, napotykali znaczne trudności w pozyskiwaniu nowych zwolenników, znaczna część robotników nie ulegała bowiem komunistycznym i rewolucyjnym hasłom, a wśród chłopów popularnością cieszyły się ugrupowania reformistyczne oraz narodowo-chrześcijańsko-demokratyczne ${ }^{6}$. Radykalizm polskich komunistów — zarówno ideologiczny, jak i programowy — prowadził ich do marginalizacji, gdyż społeczeństwo polskie odrzucało komunistów, mając świadomość, że tworzyli oni ruch destrukcyjny, całkowicie dyspozycyjny względem radzieckich ośrodków politycznych oraz zmierzający do likwidacji polskiej państwowości. Komuniści bowiem nie tylko negowali cały ustój społeczny, polityczny i gospodarczy odrodzonej Polski, lecz także byli wrogo nastawieni do samej idei niepodległości Polski. Ze względów zasadniczych całkowicie odrzucali istnienie niepodległego bytu państwa polskiego, oceniając, że przeżywana epoka jest jedynie epizodem wszechświatowej rewolucji komunistycznej. Odradzanie się polskiej państwowości uznali za zjawisko kontrrewolucyjne, będące przeszkodą w walce o wyzwolenie proletariatu. Co więcej, przewidywali, iż Polska odbuduje się jako państwo kapitalistyczne, tym samym wzmacniając światowy kapitalizm oraz osłabiając — ze względu na swe geopolityczne położenie — nadchodzącą rewolucję komunistyczną ${ }^{7}$. Ich koncepcje chociażby państwa i prawa miały całkowicie wtórny charakter względem radzieckiej myśli prawnej i politycznej ${ }^{8}$.

Pomimo antypaństwowej i szpiegowskiej działalności komunistów — tym groźniejszej, bo realizującej interesy zagrażającemu niepodległości polskiej ZSRR - KPP pozostawała ugrupowaniem legalnym jeszcze do połowy $1919 \mathrm{r}$. Stan ten wynikał z obowiązującego wówczas prawodawstwa, które stanowiło, iż partie polityczne działające legalnie w okresie zaborów nie musiały legitymować

${ }^{4}$ P. Osęka, Tomasz i jego ekipa, „Polityka. Pomocnik Historyczny” 2012, nr 6, s. 19.

5 Por. K. Trembicka, Środowisko komunistów wobec odzyskania niepodległości przez Polskę $i$ wojny polsko-bolszewickiej, [w:] Komuniści w międzywojennej Warszawie, red. E. Kowalczyk, Warszawa 2014, s. 45; H. Cimek, Komuniści, Polska, Stalin. 1918-1939, Białystok 1990, s. 8-9.

6 A. Czubiński, Komunistyczna Partia Polski. Zarys historii, Warszawa 1985, s. 30-33.

7 M. Śliwa, Polska myśl polityczna w I połowie XX wieku, Wrocław-Warszawa-Kraków 1993, s. $63-64$.

8 Por. A. Walicki, Marksizm i skok do królestwa wolności. Dzieje komunistycznej utopii, Warszawa 1996, s. 329-337; A. Bosiacki, Utopia, władza, prawo. Doktryna i koncepcje prawne bolszewickiej Rosji 1917-1921, Warszawa 2012, s. 19-45; L. Kołakowski, Marksistowskie korzenie stalinizmu, [w:] idem, Czy diabeł może być zbawiony i 27 innych kazań, Kraków 2006, s. 352-353. 
się żadnym potwierdzeniem prawnym już po odzyskaniu niepodległości, podczas gdy KPP została utworzona z Socjaldemokracji Królestwa Polskiego i Litwy (SDKPiL) oraz PPS-Lewicy, partii działających legalnie przed 1918 r. W II RP działalność komunistów była nielegalna (w praktyce zatem kolejne rządy II RP traktowały KPP jako partią nielegalną), ale sama partia komunistyczna na mocy żadnego aktu prawnego nie została formalnie zdelegalizowana. Komunista nie mógł się więc przyznać przed sądem do członkostwa w KPP, ale mógł oświadczyć, że komunizm jest jego systemem wartości i światopoglądem.

Do końca lat 20. działacze komunistyczni mogli cieszyć się względną tolerancją władz państwowych odrodzonej Polski. Stan ten zaczął się zmieniać z początkiem lat 30., gdyż obóz sanacyjny po okresie quasi-liberalizmu w pierwszych latach swoich rządów (1926-1929 r.) zaostrzył swą politykę zwalczania ruchu komunistycznego. Niemniej jednak, do końca II RP komuniści prowadzili legalną działalność na różnych płaszczyznach życia społecznego, umiejętnie wykorzystując obowiązujące prawo i narzędzia demokratycznej Polski ${ }^{9}$.

$\mathrm{Z}$ treści akt sądowych procesu łuckiego wynika, iż genezy powstania Komunistycznej Partii Zachodniej Ukrainy należy upatrywać w 1918 r. Część uchodźców z Małopolski Wschodniej utworzyła wówczas w Turkiestanie organizację komunistyczną, która po ich powrocie do Polski przekształciła się Komunistyczną Partię Galicji Wschodniej (KPGW). Partia ta początkowo była zależna od Komunistycznej Partii Bolszewików Ukrainy, natomiast po przyłączeniu Małopolski Wschodniej do Polski została w 1920 r. wcielona do Komunistycznej Partii Robotniczej Polski (nazwa KPP do 1925 r.) jako jej obwód. Od samego początku komuniści galicyjscy prezentowali tendencję do samodzielności, co rodziło spory z KPRP. W KPGW dominował bowiem kierunek nacjonalistyczny, a orientacja internacjonalistyczna, wspierana przez KPRP, była mniejszościowa ${ }^{10}$.

W 1923 r. na II Zjeździe Komunistycznej Partii Robotniczej Polski (19 września-2 października) podjęto uchwałę o zjednoczeniu wszystkich sił komunistycznych w jednej partii, gdyż zgodnie z uchwałami II Kongresu Kominternu (Międzynarodówki Komunistycznej) na terenie jednego państwa mogła istnieć tylko jedna partia komunistyczna. Pomimo tego zastrzeżenia postanowiono powołać Komunistyczną Partię Zachodniej Ukrainy oraz Komunistyczną Partię Zachodniej Białorusi jako obwodowe (autonomiczne) organizacje KPP, działające na terenach polskich na wschód od Bugu, zamieszkiwanych głównie przez ludność ukraińską i białoruską, a przez Sowietów nazywanych odpowiednio Ukrainą Zachodnią i Białorusią Zachodnią ${ }^{11}$. Komunistom ukraińskim podporządkowano organiza-

9 Z. Zaporowski, Legalna działalność nielegalnej Komunistycznej Partii Polski w Warszawie, [w:] Komuniści w międzywojennej Warszawie..., s. 204-205.

10 Akta sądowe sprawy łuckiej, Instytut Pamięci Narodowej, sygn. akt 138/33, s. 16.

11 H. Cimek, Problemy narodowościowe w Komunistycznej Partii Polski, [w:] Radykalna lewica na ziemiach polskich w latach 1893-1938: SDKPiL, KPRP, KPP, red. R. Raub, Zielona Góra 2009, s. 7. 
cje partyjne z Wołynia i Chełmszczyzny. W dalszym ciągu istniały jednak silne związki z Komunistyczną Partią Ukrainy Radzieckiej, zwłaszcza że duża część kierownictwa, redakcji partyjnej i ośrodków szkoleniowych mieściła się na terenie Ukrainy Radzieckiej. Z Komunistyczna Partia Zachodniej Ukrainy działała na terenie Lubelszczyzny, głównie w powiatach wschodnich, zamieszkałych przez ludność ukraińską. Ogółem liczba Ukraińców na Lubelszczyźnie wynosiła 210 245, co stanowiło 8,6\% ludności całego województwa. Dane te pochodzą z narady starostów w 1933 r. Dwa lata później wojewoda lubelski przyznał jednak, że liczbę ludności ukraińskiej szacowano na ok. 16\% („o ile nie więcej”). KPZU skupiała się całkowicie na obszarach wiejskich, działając w województwach południowo-wschodnich: lwowskim, stanisławowskim i wołyńskim ${ }^{12}$.

Struktura organizacyjna KPZU była analogiczna do struktury KPP. Najwyższym organem był Zjazd Partyjny, a w okresie pomiędzy poszczególnymi zjazdami - Komitet Centralny (KC). Kierownictwo KPZU składało się właściwie z dwóch części: kierownictwa krajowego, tj. Sekretariatu KC na czele z sekretarzem, uzależnionego od Sekretariatu KC KPP, oraz kierownictwa zagranicznego w postaci Biura Politycznego (politbiura KPZU), nadającego ogólny kierunek działalności partii. Obie te części tworzyły swoje terenowe jednostki: Komitety Okręgowe, Komitety Powiatowe, Komitety Dzielnicowe, Komitety Rejonowe oraz trzyosobowe komórki (tzw. jaczejki lub bojówki) będące najniższymi i podstawowymi formami organizacji partii. Komitety podzielone były na referaty. $\mathrm{Na}$ czele każdego z nich stał referent podlegający sekretarzowi odpowiedniego komitetu. Przy KC KPZU funkcjonowały wydziały: kolejowy, inteligencji, rolny, wojskowy, kobiecy, organizacyjny, a także Biuro Żydowskie. Szczególne znaczenie miał wydział techniczny, zajmujący się organizowaniem legalnych i nielegalnych drukarń, ekspedycją pism partyjnych oraz sprawami granicznymi, a więc transportem członków partii do Rosji i Niemiec oraz z powrotem do Polski. Poza wymienionymi organami partyjnymi i jednostkami pomocniczymi, funkcjonowało wielu funkcjonariuszy partyjnych pełniących przeważnie funkcje kierownicze i polityczne. Realizowali oni specjalne misje polityczne jako emisariusze i kurierzy lub odpowiadali za łączność pomiędzy organami partyjnymi. Do końca 1930 r. siedziba KC KPZU znajdowała się we Lwowie ${ }^{13}$.

Wyraźnie chłopski charakter odróżniał KPZU od „partii-matki”, a więc KPP. Działacze KPZU niemal całkowicie pomijali znaczenie proletariatu, uznając, iż rewolucja komunistyczna może być dokonana przez samych chłopów. Z poglądem tym polemizowano na V Konferencji KPZU (kwiecień 1924 r.), kładąc nacisk na pozyskanie wpływów warstwy robotniczej. Konferencja ta potępiła ponadto istniejące w partii tendencje uznawania walki sabotażowej za walkę rewolucyjną.

12 E. Horoch, Komunistyczna Partia Zachodniej Ukrainy w okregu chetmskim w latach 1924 1938: główne problemy, „Annales Universitatis Mariae Curie-Skłodowska. Sectio F, Historia” 46/47, 1991/1992, s. 451-452.

13 Sygn. akt 138/33, s. 17-55. 
Przyjęła hasła: ziemi dla chłopów, sojuszu robotniczo-chłopskiego, rewolucji socjalistycznej i dyktatury proletariatu w Polsce oraz utworzenia Ukrainy Radzieckiej z połączenia Ukrainy Zachodniej z Ukraińską Socjalistyczną Republiką Radziecką ${ }^{14}$. Ten ostatni cel stanowił źródło sporu z działaczami KPP i Kominternu, oskarżającymi KPZU o zbytnią samodzielność i separatyzm w stosunku do KPP. Ukraińscy komuniści dążyli bowiem do wywołania - z pomocą Armii Czerwonej — osobnej rewolucji na ziemiach Ukrainy Zachodniej, tym samym odrzucając konieczność wywołania rewolucji w całej Polsce, za czym opowiadali się aktywiści KPP ${ }^{15}$.

W KPZU zdecydowanie przeważała frakcja komunistów narodowych akcentujących przede wszystkim sprawę ukraińską (niezależność narodu ukraińskiego), natomiast frakcja internacjonalistów miała znikomy wpływ na charakter ugrupowania. Liczebność KPZU jest trudna do precyzyjnego ustalenia. Wynika to głównie z faktu, że KPZU była partią nielegalną; przez cały okres działała w konspiracji. Określenie liczby członków organizacji może być dokonane jedynie na podstawie materiałów samej partii. Są to przede wszystkim sprawozdania władz centralnych i dane pochodzące $z$ władz administracyjnych oraz jednostek Policji Państwowej. Te ostatnie niestety, wobec zakonspirowanej działalności partii, nigdy nie były pełne. Dane partyjne również nie uwzględniały pełnej liczby członków. Wynikało to z aresztowań członków, rozbijania komórek, braku łączności z poszczególnymi rejonami i luk w sprawozdaniach ${ }^{16}$. Wiadomo natomiast, że na początku 1926 r. KPZU liczyła ok. 2000 członków, z czego 80\% stanowili małorolni chłopi ${ }^{17}$. Po zamachu majowym i przejęciu władzy przez piłsudczyków liczba członków zaczęła spadać wskutek nasilenia aresztowań dokonywanych przez obóz sanacji.

Z KPZU współpracowały ściśle z nią związane i ideowo tożsame (bądź przynajmniej zbliżone) pomniejsze ugrupowanie komunistyczne, takie jak Komunistyczny Związek Młodzieży Zachodniej Ukrainy (KZMZU). Była to przybudówka KPZU, organizacja młodzieżowa o niemal identycznej jak KPZU strukturze organizacyjnej (nie posiadała wydziału wojskowego). Prowadziła działalność wśród młodzieży zarówno wiejskiej, jak i miejskiej, szkolnej i akademickiej (w środowisku akademickim działała legalnie poprzez takie organizacje jak: ,Życie” i „Studencka Hromada”) oraz wśród dzieci i stowarzyszeń młodzieżowych. Innym ugrupowaniem ściśle związanym z KPZU była Międzynarodowa Organizacja Pomocy Rewolucjonistom (MOPR). Udzielała ona pomocy materialnej, prawnej i moralnej komunistom odbywającym wyroki w więzieniach. Koordynowała proces tworzenia w więzieniach tzw. komun więziennych, zrzeszających

${ }^{14}$ H. Cimek, L. Kieszczyński, Komunistyczna Partia Polski 1918-1938, Warszawa 1984, s. 128.

15 Ibidem.

16 E. Horoch, op. cit., s. 454-455.

17 H. Cimek, L. Kieszczyński, op. cit., s. 150. 
komunistów i innych więźniów skazanych za działalność antypaństwową. Opierała się na ideologii Kominternu, przez co stanowiła ważny filar ruchu komunistycznego w Polsce ${ }^{18}$.

KPZU nie tylko współpracowała $\mathrm{z}$ innymi organizacjami, lecz także w ciągu swego istnienia wiele $\mathrm{z}$ nich opanowała lub zbudowała. Były to ugrupowania programowo zbliżone do komunistów, przeważnie szybko likwidowane, wśród których można wymienić: Ukraińską Socjal-Demokratyczną Partię (rozwiązana w 1924 r.), Niezależną Partię Chłopską i Białoruską Włościańską Robotniczą Hromadę (rozwiązane w 1927 r.), PPS-Lewicę i Polską Partię Socjalistyczną oraz Partię Narodnej Woli (rozwiązana w 1929 r.) ${ }^{19}$.

Niemal cała działalność KPZU skupiała się na dążeniu do oderwania terenów południowo-wschodniej Polski i ustanowienia na nich komunistycznej, totalitarnej dyktatury na wzór radziecki. W tym celu ukraińscy komuniści prowadzili akcje propagandowe skierowane głównie do ukraińskiego chłopstwa, choć także do robotników i inteligencji. KPZU do swych celów wykorzystywała wszelkie strajki i tarcia na tle socjalnym i ekonomicznym, starała się wzmacniać dążenia separatystyczne mniejszości narodowych. Szczególnym obiektem zainteresowania partii był polski rząd, zaciekle atakowany przez działaczy KPZU — rząd II RP określany był jako faszystowski i okupacyjny; zarzucano mu stosowanie terroru, uciskanie mniejszości narodowych, a także oskarżano o agresję i przygotowywanie wojny przeciwko Rosji Radzieckiej, a następnie ZSRR. Jednocześnie przeprowadzano akcje propagandowe i agitacyjne na rzecz Sowietów, głównie w szeregach poborowych oraz wśród członków organizacji przysposobienia wojskowego i wychowania fizycznego. Starano się tym samym osłabić zdolności militarne Polski. Działacze KPZU popierali też strajki i sabotaże dokonywane przez Ukraińską Organizację Wojskową (UWO) ${ }^{20}$.

Początki sprawy łuckiej sięgają $1930 \mathrm{r}$. Wówczas to policja polska zatrzymała Jana Kozaka, pełniącego funkcję instruktora Komitetu Centralnego KPZU. Kozak, mający obszerną wiedzę o partii ukraińskich komunistów, podjął współpracę z polskimi służbami, ujawniając wiele informacji o działaczach, strukturach i działalności KPZU. Został również wykorzystany w licznych prowokacjach policyjnych zakończonych aresztowaniem kilkudziesięciu aktywistów KPZU na czele z Ozjaszem Szechterem, szefem Wydziału Zawodowego KC KPZU, oraz Mikołajem Pawłykiem, sekretarzem KC KPZU ${ }^{21}$. Sąd w Łucku z ostrożnością potraktował zeznania świadka Kozaka, mając świadomość, iż był on ważną figurą w organizacji, nie wyrzekł się swych komunistycznych przekonań i nie od początku przystał na dobrowolną współpracę. Ponadto, jak podkreślił w uzasadnieniu wyroku sąd:

18 Sygn. akt 138/33, s. 24.

19 Ibidem, s. 21.

20 Ibidem, s. 19.

21 P. Gontarczyk, Zwyczajna agentura, „Biuletyn Instytutu Pamięci Narodowej” 2008, nr 1112 (94-95), s. 93. 
czytając te [Kozaka] zeznania odnosi się wrażenie, iż komunistyczna partja to jakaś utajona i nieuchwytna potęga, która jest wszędzie i wszystkim kieruje w myśl swoich interesów we wszystkich dziedzinach życia społeczno-politycznego i gospodarczego [...]. Wszystko tam dzieje się przez Kompartję i nic poza nią 22 .

Kozak, ujęty na gorącym uczynku, był zaskoczony obszerną wiedzą polskich służb o KPZU i wiedział, że i bez jego zeznań innych działaczy czekają aresztowania. Zdecydował się zatem zeznawać z pobudek czysto kalkulacyjnych, mając na uwadze jedynie własny interes i licząc na łagodny wymiar kary, a nawet odzyskanie wolności. Niemniej sąd w uzasadnieniu wyroku podkreślił, iż

[Kozak] miał do wyboru - albo dobić organizację swemi informacjami i liczyć na pewne względy, nawet odzyskanie wolności, albo też zasiąść na długie lata w więzieniu, i jako człowiek przebiegły wybrał pierwsze wyjście, a zdecydowawszy się raz na to, za wszelką cenę już mógł i musiał niewątpliwie dążyć do odzyskania wolności i w tym celu zasypywać swych współtowarzyszów partyjnych i może nawet tych wszystkich, z którymi kiedykolwiek miał jaką bądź styczność, czy to na tle partyjnem, czy też innem, jednych słusznie, drugich może niesłusznie, przytaczając z wprost zadziwiającą pewnością siebie i dokładnością imiona, nazwiska, pseudonimy, miejscowości, fakty, daty i okoliczności, które miały miejsce w ciągu kilku lat, co razem wskazywałoby na jakąś fenomenalną pamięć i wybitne zdolności tego człowieka $^{23}$.

Proces sądowy łącznie 57 oskarżonych, działaczy KPZU, toczył się przed Wydziałem Karnym Sądu Okręgowego w Łucku. Z akt śledztwa (sygn. akt 138/33) prowadzonego przez Sędziego Apelacyjnego Śledczego do spraw wyjątkowego znaczenia w Warszawie, Jana Demanta, wynika, że wszystkim oskarżonym zarzucono popełnienie zbrodni stanu (zdrady głównej) na podstawie art. 97, par. 1 w związku z art. 93, par. 1 kodeksu karnego z 1932 r., tj. kodeksu Makarewicza ${ }^{24}$. Kodeks ten był ukoronowaniem podejmowanych od 1918 r. prób kodyfikacji różnych systemów prawnych na terenie II RP, gdyż w latach 1918-1932 wciąż obowiązywał rosyjski kodeks karny z 1903 r., tzw. kodeks Tagancewa.

W materiałach śledztwa czytamy, iż oskarżeni dopuścili się zbrodni zdrady stanu, gdyż jako członkowie nielegalnej, terrorystyczno-rewolucyjnej i działającej w konspiracji partii komunistycznej organizowali komitety KPZU i ZMK, werbowali nowych członków, zajmowali się kolportażem literatury partyjnej oraz wygłaszali antypaństwowe przemówienia wychwalające idee komunistyczne. Działania te zmierzały do wywołania rewolucji w Polsce i ustanowienia komunistycznych rządów robotniczo-chłopskich oraz połączenia się z Rosją Sowiecką ${ }^{25}$.

22 Sygn. akt 138/33, s. 13.

23 Ibidem.

${ }^{24}$ Art. 93: „Kto usiłuje pozbawić państwo polskie niepodległego bytu lub oderwać część jego obszaru, podlega karze więzienia na czas nie krótszy od lat 10 lub dożywotnio albo karze śmierci. Kto usiłuje przemocą zmienić ustrój Państwa Polskiego, podlega karze więzienia na czas nie krótszy od lat 10 lub dożywotnio”. Art. 97, par. 1: „Kto w celu popełnienia przestępstwa, określonego w art. 93, 94 lub 95, wchodzi w porozumienie z innymi osobami, podlega karze więzienia”.

25 Sygn. akt 138/33, s. 5. 
Oskarżeni działacze KPZU od samego początku mogli liczyć na pomoc swych sowieckich mocodawców. Obronę oskarżonych koordynował bowiem adwokat Teodor Duracz. Prawnik ten, oficjalnie zatrudniony w sowieckim przedstawicielstwie handlowym w Warszawie, w rzeczywistości był już od $1918 \mathrm{r}$. członkiem KPRP-KPP, a rok wcześniej brał udział w rewolucji październikowej. Był jednym z najważniejszych ludzi Stalina w przedwojennej Polsce, gdyż występował jako obrońca w licznych procesach politycznych komunistów oskarżonych o działalność szpiegowską na rzecz ZSRR. W jego mieszkaniu i kancelarii skupiały się rozmaite nici komunistycznej konspiracji i sowieckiego wywiadu. Duracza, którego polska prasa wprost określała mianem radzieckiego agenta, polskie władze próbowały wydalić z kraju, jednakże starania te okazały się nieskuteczne ze względu na obowiązujące prawodawstwo. W 1943 r. prawnik zostanie zamordowany przez Gestapo na Pawiaku, ale warto dodać, że w powojennej Polsce rządzący komuniści imieniem Duracza nazwą słynną Centralną, a następnie Wyższą Szkołę Prawniczą w Warszawie — ośrodek kształcenia przyszłych kadr sądowo-prokuratorskich, istniejący w latach 1948-1953 (stąd tzw. duraczówka).

Pomoc oskarżonym działaczom KPZU okazywała również Helena Michnik, żona jednego z głównych oskarżonych, Ozjasza Szechtera. Helena Michnik, oficjalnie będąca asystentką jednego z adwokatów biorących udział w sprawie, a faktycznie komunistyczna agentka, przepisała materiały sądowe stanowiące największe zagrożenie dla dalszego istnienia KPZU. Przede wszystkim interesowały ją informacje ujawnione przez Kozaka. Helena Michnik po latach wspominała:

[...] późnym latem $1933 \mathrm{r}$. Rozenbusch, który wtedy był w kraju i był członkiem sekretariatu krajowego [KPZU] powiedział mi, że koniecznie potrzebny jest materiał zeznań oskarżonych i prowokatorów w procesie łuckim, że to trzeba koniecznie wydostać [...] Miałam takie polecenie. Przede wszystkim miałam dosłownie przepisać zeznania Kozaka, bo to jest najistotniejsze, oraz wszystkie inne konkretne materiały rzeczowe. [...] Przepisałam dosłownie zeznania policyjne sądowe Jaworskiego, zeznanie policyjne Kozaka. Z zeznań innych towarzyszy wszystko to, co mogło być potrzebne do archiwum partyjnego. Ja zbierałam te materiały pod dwoma punktami widzenia $-\mathrm{z}$ jednej strony dla partii, $\mathrm{z}$ drugiej - dla obrony ${ }^{26}$.

Ze względu na wielkie zainteresowanie prasy, komuniści od samego początku traktowali proces łucki jako doskonałą okazję do propagowania swej ideologii i programu. Wydaje się nawet, że przyjęta linia obrony miała na celu nie tyle dobro oskarżonych (jak najniższy wyrok), ile wychwalanie komunizmu i dyskredytowanie państwa polskiego. Zgodnie z nią usiłowano dowieść, że oskarżeni są niewinnymi ofiarami represji państwa polskiego i biorą udział w teatrze politycznym, co miało potwierdzać lansowaną przez komunistów tezę o faszystowsko-dyktatorskim charakterze rządów Piłsudskiego. Przygotowano w tym celu szereg wystąpień propagandowych uderzających w ustrój ówczesnej Polski oraz wychwalających ZSRR i ideologię komunistyczną, m.in. zarówno w więzieniu,

26 P. Gontarczyk, op. cit., s. 94. 
jak i na sali sądowej śpiewano pieśni komunistyczne. Naczelnik więzienia karno-śledczego w Łucku w pismach kierowanych do prokuratora Sądu Okręgowego w Łucku regularnie donosił o buntowniczym i prowokacyjnym zachowaniu osadzonych komunistów. Informował w nich, że zachowywali się oni agresywnie wobec personelu, śpiewali Międzynarodówkę, zakładali czerwone kokardy z okazji święta 1-majowego.

Inną formą protestu komunistów było organizowanie głodówek. W zawiadomieniu starszego dozorcy policyjnego, skierowanym do naczelnika więzienia w Łucku 11 maja 1932 r., czytamy, że melduje on, iż „w dniu dzisiejszym podczas apelu rannego więźniarka komunistka Blumenkranc Chiża oświadczyła w imieniu całej celi, że protestacyjną głodówkę przeciw krwawemu faszyzmowi przerywają i na przyszłość będą stosowali inne środki, ponieważ głodówka nie przynosi skutku"27.

Kwestią niewyjaśnioną pozostaje stosowanie przymusu fizycznego i psychicznego wobec aresztowanych komunistów. Nie da się precyzyjnie określić, na ile była to przyjęta przez działaczy KPZU linia obrony oraz forma zanegowania wartości dowodowej i prawdziwości złożonych przez nich w toku śledztwa zeznań, a na ile rzeczywisty wyraz złamania prawa przez śledczych. Oskarżeni utrzymywali, iż były stosowane wobec nich rozmaite formy nacisku fizycznego i były im podsuwane do podpisania gotowe protokoły zeznań. W uzasadnieniu wyroku sąd odniósł się również do tej kwestii, zaznaczając, iż prawie wszyscy oskarżeni, w tym nawet ci, którzy nie przyznali się do winy, przez cały czas trwania procesu podkreślali, iż byli bici, zastraszani i w inny sposób torturowani. Wśród rzekomo stosowanych wobec nich metod wymienili: bicie w pięty, po organach płciowych, rzucanie o ziemię, wlewanie wody do nosa, morzenie głodem i zastraszanie. Sąd jednak podkreślił, że w opisywaniu kolejnych metod tortur oskarżeni posunęli się „tak dalece, że zdaje się, zapomnieli o tem, iż podobnych katuszy, o jakich mówili, najprawdopodobniej nie przeżyliby, a już niewątpliwie mieliby na sobie ślady w postaci tych, lub innych kalectw, względnie zmian na ciele, czego jednak sądowo-lekarskimi oględzinami, jakich nie ma powodów podawać w wątpliwość, nie ujawniono". Sąd nie uwzględnił zarzutów oskarżonych dotyczących stosowania wobec nich tortur, uzasadniając swoje stanowisko praktyką postępowania oskarżonych działaczy komunistycznych, którzy niemal w każdym procesie sądowym podważają praworządność instytucji i organów II RP, szczególnie poprzez oskarżanie ich o stosowanie niedozwolonych metod śledczych. W ocenie sądu postawa oskarżonych wynikała ze złamania ich woli, spowodowanego zaskoczeniem, tj. nieoczekiwanym dla nich wykryciem przez organy bezpieczeństwa ich zbrodniczej działalności, co z natury rzeczy działa deprymująco na psychikę sprawców, łamiąc - lub przynajmniej osłabiając - ich hart i wolę oporu ${ }^{28}$.

27 Sygn. akt 138/33, s. 61.

28 Ibidem, s. 10. 
Ponadto sąd stwierdził, iż wykluczone jest, by protokoły zeznań nie zawierały tego, co oskarżeni w trakcie śledztwa zeznali, lub by zeznawali przed sędzią śledczym pod jakąkolwiek presją, przymuszeni niedozwolonymi metodami przesłuchiwania. Zdaniem sądu oskarżenia były wyrazem taktyki przyjętej przez oskarżonych, zmierzającej do zdyskredytowania organów sądowych. Co więcej, prowokacyjną postawę oskarżeni przyjęli także na rozprawie, zachowując się momentami tak, jakby chcieli wyprowadzić skład sędziowski z równowagi. Tym samym dążyli oni do sprowokowania represji, co pozwoliłoby im kreować się na męczenników i ofiary „białego terroru” i „,burżuazyjnego wymiaru sprawiedliwości”"29.

Sąd nie dał wiary zeznaniom oskarżonych, jakoby byli oni poddawani torturom, jednakże stwierdził również, iż samo zaprzeczenie służb biorących udział w śledztwie i likwidacji działalności komunistycznej jest niewystarczające do jednoznacznego rozstrzygnięcia sprawy. Sąd powołał się w tym kontekście na oświadczenie ministra spraw wewnętrznych gen. Felicjana Sławoja-Składkowskiego, złożone w Sejmie i Senacie 3 lutego 1931 r. Wystąpienie to dotyczyło rzekomego bicia, jakiego mieli dopuszczać się policjanci wobec przebywających w Łucku zatrzymanych i aresztowanych. Minister stwierdził, iż:

co do Łucka, aczkolwiek w tych wypadkach są rzeczy, które są sądownie niesłychanie trudne do dowiedzenia, nabrałem wewnętrznego przekonania, że nie wszystko jest w porządku [...] Stwierdzam jednak niezdrową atmosferę w Urzędzie Śledczym w Łucku, doszedłem do przekonania, że nie ma innego wyjścia, jak rozpędzenie tego urzędu. Co też 10 dni temu zrobiłem ${ }^{30}$.

Wiele zatem przemawia za przynajmniej częściową prawdziwością oskarżeń komunistów o stosowanie niedozwolonych metod przez polskie organy ścigania, których funkcjonariusze śledczy dopuścili się przekroczenia swych uprawnień i łamania prawa.

Materiał dowodowy stanowiły w pierwszej kolejności zeznania świadka Kozaka, a także wyjaśnienia i oświadczenia samych oskarżonych. Ponadto za podstawę wyrokowania sąd przyjął zeznania byłych członków KPZU oraz zeznania funkcjonariuszy policji, a także dane konfidencjonalne i dane $\mathrm{z}$ obserwacji, uzyskane przez rozpracowujących KPZU funkcjonariuszy Policji Politycznej na terenie Małopolski Wschodniej. W toku śledztwa i procesu zgromadzono również wiele dowodów rzeczowych w postaci rękopisów, notatek, wydawnictw KPZU, broszur i referatów oraz innych ujawnionych u niektórych oskarżonych dokumentów $\mathrm{i}$ informacji ${ }^{31}$.

Większość oskarżonych nie przyznała się do winy ani nawet do członkostwa w KPZU, do końca utrzymując, że ich wyjaśnienia zostały w śledztwie wymuszone. Wspomniany wyżej Ozjasz Szechter oświadczył jednak, że ,jest przekonań komunistycznych, których nabył ze studiów ekonomicznych i socjalnych, jest

29 Ibidem, s. 11.

30 Ibidem.

31 Ibidem, s. 8-9. 
marksistą i sympatykiem komunizmu i zawsze będzie o te swoje przekonania, których nigdy nie ukrywał, walczył" 32 . Wyrok w sprawie łuckiej zapadł 14 kwietnia 1934 r.:

Sąd Okręgowy w Łucku na posiedzeniu sądowym w składzie St. Dziewulski i W. Dobrowolski pod przewodnictwem prezesa A. Nowakowskiego, rozpoznawszy sprawę Mikołaja Pawłyka i innych oskarżonych o to, że do dnia aresztowania - na terenie Państwa Polskiego, a w szczególności - Wołynia, wschodniej części województwa Lubelskiego / Chełmszczyzny / Małopolski Wschodniej, należąc do KPZU, tem samym weszli w porozumienie z innymi osobami w celu oderwania od Państwa Polskiego południowo-wschodnich województw i przyłączenia ich do ZSRR, oraz w celu zmiany przemocą ustroju Państwa Polskiego i zastąpienia go ustrojem komunistyczno-radzieckim, przyczem związek ten - KPZU — rozporządzał składem broni, uznać winnymi oskarżonych $[\ldots]^{33}$.

Wszystkich oskarżonych uznano winnymi popełnienia zarzucanych im czynów. Kary opiewały na od trzech do ośmiu lat pozbawienia wolności (najwyższą karę ośmiu lat więzienia otrzymało 14 oskarżonych, w tym sekretarz partii Mikołaj Pawłyk i Ozjasz Szechter). Dodatkowo wszyscy oskarżeni pozbawieni zostali praw publicznych oraz obywatelskich praw honorowych na okres lat dziesięciu. Sąd, mając jednak na uwadze długotrwałość śledztwa i tymczasowego aresztowania, spowodowaną dużą liczbą oskarżonych, uznał za słuszne zaliczenie na poczet orzeczonej skazanym kary czasu aresztu tymczasowego. Wszyscy oskarżeni zostali zwolnieni z konieczności uiszczenia opłat sądowych ze względu na ich trudną sytuację materialną, a koszty postępowania zasądzono tylko od niektórych. W uzasadnieniu wyroku sąd zaznaczył, iż po analizie materiału dowodowego doszedł do wniosku, że wyjaśnienia i oświadczenia tylko siedmiu oskarżonych (w tym Mikołaja Pawłyka) zawierają:

nacechowanie nienawiścią przeciwko obecnemu ustrojowi polityczno-społecznemu i złożone w tonie i formie napastliwej stanowią bezpośredni i niesporny dowód ich udziału w Komunistycznej Partii Zachodniej Ukrainy, a tem samem i dowód zarzucanej im winy, gdyż pierwsi siedmiu oświadczyli otwarcie i wyraźnie, iż są i byli członkami Komunistycznej Partii Zachodniej Ukrainy $[\ldots]^{34}$.

Odnosząc się do wyjaśnień pozostałych oskarżonych, sąd w uzasadnieniu wyroku stwierdził, iż:

jakkolwiek nacechowane również duchem rewolucyjnym i duchem nienawiści i buntu przeciwko istniejącemu porządku społecznemu, to jednak same przez się nie dowodzą przynależności tych oskarżonych do Komunistycznej Partji, a tylko w wysokim stopniu charakteryzują i odzwierciedlają ich zapatrywania i dążenia polityczno-społeczne oraz obrane przez nich metody walki o zrealizowanie swych ideałów, ideałów o charakterze wybitnie komunistycznym, tak że już na podstawie tych wyjaśnień można wnioskować, iż ma się do czynienia z ludźmi o ideologii wręcz komunistycznej, względnie mało różniącej się od niej i dlatego też wyja-

32 Ibidem, s. 34.

33 Ibidem, s. 12.

34 Ibidem, s. 119.

Studia nad Autorytaryzmem i Totalitaryzmem 38, nr 3, 2016

(C) for this edition by CNS 
śnienia te uznane zostały za bardzo obciążające dla oskarżonych, a w połączeniu z innymi obiektywnie stwierdzonymi okolicznościami, za niewątpliwy dowód udziału w komunistycznej partii ${ }^{35}$.

Większość skazanych komunistów odzyska wolność już rok później na mocy amnestii, która będzie skutkować ich przedterminowym zwolnieniem, jednakże niektórych z nich dosięgną represje ze strony własnej partii. Umożliwiły to kopie akt sądowych dokonane przez Helenę Michnik. KPP obawiała się, iż w toku śledztwa i procesu pozyskano zbyt wiele informacji o partii komunistycznej, jej działalności i członkach. Wobec tego uznano, że dalsza przynależność do KPP jej zdekonspirowanych działaczy zagraża istnieniu partii. Część aktywistów KPZU została usunięta z partii, a inni (np. Szechter) zostali zawieszeni. Błędem byłoby jednak przypuszczenie, że na tej podstawie wyrzekli się oni swych komunistycznych poglądów, część z nich bowiem odegra niechlubną rolę podczas II wojny światowej i w okresie stalinowskiej Polski, jak np. Enzel Stup w 1939 r. dowodzący w Kobryniu komunistyczną gwardią robotniczą, mordującą polskich żołnierzy i policjantów ${ }^{36}$.

\title{
Bibliografia
}

Akta sądowe sprawy łuckiej, Instytut Pamięci Narodowej, sygn. akt 138/33.

Bosiacki A., Utopia, władza, prawo. Doktryna i koncepcje prawne bolszewickiej Rosji 1917-1921, Warszawa 2012.

Cimek H., Komuniści, Polska, Stalin. 1918-1939, Krajowa Agencja Wydawnicza, Białystok 1990.

Cimek H., Kieszczyński L., Komunistyczna Partia Polski 1918-1938, Warszawa 1984.

Czubiński A., Komunistyczna Partia Polski. Zarys historii, Warszawa 1985.

Gontarczyk P., Zwyczajna agentura, „Biuletyn Instytutu Pamięci Narodowej” 2008, nr 11-12 (94-95).

Horoch E., Komunistyczna Partia Zachodniej Ukrainy w okręgu chetmskim w latach 1924-1938: główne problemy, „Annales Universitatis Mariae Curie-Skłodowska. Sectio F, Historia” 46/47, 1991/1992.

Iwaniuk S., Prawdy i mity o KPZB, „Czasopis” 2008, nr 12 (215).

Kołakowski L., Marksistowskie korzenie stalinizmu, [w:] idem, Czy diabeł może być zbawiony i 27 innych kazań, Kraków 2006.

Komuniści w międzywojennej Warszawie, red. E. Kowalczyk, Warszawa 2014.

Komunizm w Polsce. Zdrada, zbrodnia, zakłamanie, zniewolenie, red. M. Kuś, Kraków 2012.

Łukasiewicz S., Zdrada stanu. Działalność Komunistycznej Partii Zachodniej Biatorusi w Wilnie w latach 1930-1935, „Ogrody Nauk i Sztuk” 2012, nr 2.

Osęka P., Tomasz i jego ekipa, „Polityka. Pomocnik Historyczny” 2012, nr 6.

Radykalna lewica na ziemiach polskich w latach 1893-1938: SDKPiL, KPRP, KPP, red. R. Raub, Zielona Góra 2009.

Reguła J.A., Historia Komunistycznej Partii Polski w świetle faktów i dokumentów, Toruń 1994.

Śliwa M., Polska myśl polityczna w I połowie XX wieku, Wrocław-Warszawa-Kraków 1993.

Walicki A., Marksizm i skok do królestwa wolności. Dzieje komunistycznej utopii, Warszawa 1996.

\author{
35 Ibidem. \\ 36 P. Gontarczyk, op. cit., s. 96.
}

Studia nad Autorytaryzmem i Totalitaryzmem 38, nr 3, 2016

(C) for this edition by CNS 
COMMUNIST PARTY OF WESTERN UKRAINE AND THE SO-CALLED LUCK TRIAL

\section{Summary}

Communist Party of Poland (KPP), operating within the territory of the Second Polish Republic, displayed strong racially-motivated separatist tendencies, which lead to the creation of the Communist Party of Western Ukraine (KPZU) - an autonomous movement operating within the KPP structures. In the mid-thirties of 20th century KPZU activists were put in the dock in the so-called Luck trial, the most prominent trial of communists in pre-war Poland. Drawing mainly upon court records, the author presents the history of this marginal political party and describes the Luck trial.

Keywords: Communist Party of Western Ukraine, Luck trial, Communist Party of Poland, communists in the Second Polish Republic.

Łukasz Bojko

lukasz.bojko88@wp.pl 